Journal of American Studies, 56 (2022), 2, 242-266

(C) The Author(s), 202 r. Published by Cambridge University Press in association with the British Association for American Studies. This is an Open Access article, distributed under the terms of the Creative Commons Attribution licence (https://creativecommons.org/licenses/by/4.o/), which permits unrestricted re-use, distribution, and reproduction in any medium, provided the original work is properly cited.

doi:10.1017/S0021875821000852 First published online 06 October 2021

\title{
Native Bondage, Narrative Mobility: African American Accounts of Indian Captivity
}

\author{
ASTRID HAAS
}

The article studies African American narratives of indigenous captivity from its emergence in the mid-eighteenth century to the mid-nineteenth. Taking accounts by Briton Hammon, John Marrant, Henry Bibb, and James Beckwourth as examples, the essay charts the development of this body of writings, its distinction from white-authored narratives, and its contribution to North American autobiography. In so doing, the article argues that the black-authored texts strategically employed only certain elements of the Indian captivity narrative and that they blended these with aspects of other types of Western autobiography to claim black people's agency and discursive authority in white-dominated print culture.

Narratives about nonindigenous people's captivity and bondage with indigenous nations represent the oldest text genre to emerge specifically in British North America. The reality of Amerindian captivity and the texts' blend of didactic and entertaining elements quickly popularized the genre. ${ }^{1}$ Owing to a racialized stratification and access to literacy and print culture, most of these narratives were authored by white English settlers. Yet there is also a body of writing that testifies to African American experiences of Amerindian captivity. The largest group of such testimonies are several volumes of oral-history accounts recorded in the 1930 s. $^{2}$ However, a small

Institute for Black Atlantic Research, University of Central Lancashire. Email: ahaas2@uclan.ac.uk.

${ }^{1}$ Heiner Bus, "Lost and B/Found: The Potential of American Slave and Captivity Narratives," in Alfred Hornung, ed., Intercultural America (Heidelberg: Winter, 2007), 75-89, 75; Gordon M. Sayre, "Introduction," in Sayre, ed., American Captivity Narratives: Olaudah Equiano, Mary Rowlandson, and Others. Selected Narratives with Introduction (Boston: Wadsworth, 2000), I-I 7, 3-4.

${ }^{2}$ Keith Michael Green, Bound to Respect: Antebellum Narratives of Black Imprisonment, Servitude, and Bondage, I8I6-I86I (Tuscaloosa: University of Alabama Press, 2015), 7677; Patrick Neal Minges, "Introduction," in Minges, ed., Black Indian Slave Narratives (Winston-Salem, NC: Blair, 2004), xv-xxiii, xxi. 
corpus of texts exists in which black narrators record their experience of indigenous captivity from the mid-eighteenth century to the onset of the Civil War in $\mathrm{I} 86 \mathrm{I}$. This period is particularly interesting, as it witnessed fundamental political and territorial changes in North America that crucially affected the black experience in the region and informed the emergence of African American letters taking place at the time.

In the present article, I chart the development of the black-authored Indian captivity narrative during its first hundred years against the backdrop of interethnic relations, practices of captivity, and different types of autobiography. My analysis is based on four exemplary texts that articulate the black socioeconomic, cultural, and spatial experience. They include the Massachusetts slave Briton Hammon's Narrative of the Uncommon Sufferings and Surprising Deliverance of Briton Hammon (1760), the free black preacher John Marrant's A Narrative of the Lord's Wonderful Dealings with John Marrant, a Black (1785), the abolitionist activist Henry Bibb's Narrative of the Life and Adventures of Henry Bibb, an American Slave (1849), and the mountain man James Beckwourth's The Life and Adventures of James P. Beckwourth (1856). Each of these texts has been well researched, and Hammon's and Marrant's works have been specifically discussed as captivity narratives. However, the present article is the first comparative study of the four accounts and the first endeavor to chart the development of blackauthored accounts of indigenous captivity in North America during the Age of Revolutions and its immediate aftermath.

I argue that this body of texts represents a hybrid autobiographical genre which strategically blends elements of the Indian captivity narrative with aspects of at least one other popular type of North American life writingthe English "comparative" captivity narrative, the missionary memoir, the black slave narrative, and the western borderlands autobiography. Each of my four case studies integrates an Indian captivity story to use the esteem of this text type for conveying the black experience to white audiences, winning readers' sympathy for black authors, and endowing black people with the authority to address whites as fellow Christians, British subjects, or American compatriots. At the same time, these integrated accounts of Indian captivity and servitude innovate the captivity genre, as they frame indigenous captivity not as a "savage threat" to white civilization but as a springboard for black liberation and at least a certain degree of social agency in white-dominated North American society and print culture. Despite their considerable differences in time of writing, geographic location, and specific social context, the strategic appropriation and hybridization of the Indian captivity story render Hammon's, Marrant's, Bibb's, and Beckwourth's accounts exemplars of a distinctly African American form of the genre. 


\section{INDIGENOUS CAPTIVITY AND THE INDIAN CAPTIVITY NARRATIVE}

From the time of the first European colonization endeavors in North America, white colonists and the region's indigenous nations struggled for survival and land use. Raids and kidnappings were practiced by both sides as well as among different indigenous groups. They served to weaken enemies, obtain desired provisions, gain social status, and/or make human hostages, to be kept as slaves or diplomatic pawns, or to obtain a ransom. In contrast to the European colonizers, many Native nations also captured people of African descent. Among the Amerindian population, practices of captivity varied widely. Many tribes integrated captives into their societies, and some of them even adopted captives to replace lost family members. Other indigenous nations not only enslaved captives but also traded black slaves with white owners. Similarly, when encountering black fugitives from slavery, some indigenous nations returned or sold these people to their white claimants for ransom or as signs of peace, while others granted them refuge. ${ }^{3}$

The term "Indian captivity narrative" designates a diverse body of writings from the colonial era to the early twentieth century that deals with a nonindigenous person's capture by and bondage among a band of North American Natives. ${ }^{4}$ These writings articulated changing interethnic relations, sought to satisfy readers' desire for curiosity about Amerindians, and at times also pursued a social agenda, such as providing agency to women or exhorting settlers to piety. Above all, the texts justified white land taking, political rule, and violent subjugation and removal of indigenous nations. ${ }^{5}$ Most Indian captivity narratives are first-person accounts told in retrospect after the captive's rescue. They typically include the protagonist's capture by a band of Natives, the narrator's stationary confinement or enforced removal(s) through unknown terrain, and their escape or release from captivity. Although they testify to suffering violence and privations during their bondage, many captivity narrators not only voiced fear of their captors but also a certain fascination

${ }^{3}$ Renate Bartl, "Native American Tribes and Their African Slaves," in Stephan Palmié, ed., Slave Cultures and the Cultures of Slavery (Knoxville: University of Tennessee Press, I 995), I 62-75, 164-66; Barbara Krauthamer, Black Slaves, Indian Masters: Slavery, Emancipation, and Citizenship in the Native American South (Chapel Hill: University of North Carolina Press, 2013); Jane T. Merritt, At the Crossroads: Indians and Empires on a Mid-Atlantic Frontier, ${ }_{1700-1763}$ (Chapel Hill: University of North Carolina Press, 2003), 55, I80, 294-95.

${ }^{4}$ Bus, 75-83; Sayre, 5, I0.

5 Sayre, 4-5, 9-I 5; Pauline Turner Strong, Captive Selves, Captivating Others: The Politics and Poetics of Colonial American Captivity Narratives (Boulder, CO: Westview Press, 1999), 3-4, 7; Rafia Zafar, We Wear the Mask: African Americans Write American Literature, $1760-1870$ (New York: Columbia University Press, I997), 4I-44. 
with Native cultures. ${ }^{6}$ However, the "captivating" potential of indigenous societies is contained in the "literary imperialism" of the narratives. 7 To reintegrate into their communities of origin and to publish their accounts, captivity narrators had to refute any suspicion of having integrated into their captors' society. Their texts not only ventriloquize indigenous voices but also downplay white settler violence by depicting indigenous societies as devoid of "civilization," rendered manifest to white audiences in the captors' nomadic way of life, acts of cruelty, pagan practices, and linguistic difference. Though often based on captives' experiences, these elements have come to double in captivity narratives as telltale tropes of indigenous "savage" alterity. ${ }^{8}$

Even more than for white writers, the Indian captivity narrative "offered an entryway into print culture for African Americans." 9 The genre was open to the stories of the socially marginalized. Yet they had to convey their experiences to hegemonic audiences invested in white civilizational "superiority" and Protestant Christianity. Moreover, like white women, black authors were usually obliged to collaborate with white male editors, whose testimonies verified the identities of the narrators and the authenticity of their accounts. ${ }^{10}$ The narrative texts, Jeffrey Gagnon observes, 'incorporate[d] the black author[s'] own version[s] of events in combination with the political agendas of [their] publishers" and the expectations of their white target readers. ${ }^{\text {I I }}$ Illiterate authors further had to rely on white amanuenses to pen their stories, and either the scribes or the editors often "arranged" the dictated accounts and "improved" their language. According to William Andrews, the editors wielded "ultimate control" over the manuscripts and their placement in white print culture. ${ }^{\mathrm{I} 2}$ Yet, following Rafia Zafar, I argue that, despite these limitations, "the black self can materialize in a white frame, however incompletely." ${ }_{13}$ In line with Karen Weyler, I specifically read black-authored captivity narratives as works of autoethnography. By appropriating the language and cultural conventions of the dominant society, they enable "colonized subjects ... to represent themselves in ways that engage with the colonizer's terms ... in response to or in dialogue with those

${ }^{6}$ Sayre, 5, 9, I I-I 2; Strong, 8.

${ }^{8}$ Ibid., 43-45; Bus, 8 I-85; Sayre, 3, 8, I I-I 4.

Zafar, 44.

9 Strong, 184 .

${ }^{10}$ William L. Andrews, To Tell a Free Story: The First Century of African American Autobiography (Urbana: University of Illinois Press, 1986), 38; Karen A. Weyler, Empowering Words: Outsiders and Authorship in Early America (Athens: University of Georgia Press, 2013), 76, 83-84.

${ }^{\prime \prime}$ Jeffrey Gagnon, "'They Us'd Me Pretty Well:' Briton Hammon and Cross-cultural Alliances in the Maritime Borderlands of the Florida Coast," in Nicole N. Aljoe and Ian Finseth, eds., Journeys of the Slave Narrative in the Early Americas (Charlottesville: University of Virginia Press, 2014), 74-100, 79-80.

12 Andrews, 21, also 19-20, 33-38; Weyler, 84.

${ }^{13}$ Zafar, 55, also 42, 51-54. 
representations." ${ }^{4}$ Thus I view the four narratives I discuss in the following as articulations of black discursive agency that at least partially subverts the Anglocentric perspectives they were obliged to pursue.

\section{COMPARATIVE CAPTIVITIES IN THE NARRATIVE OF BRITON HAMMON}

The first known black-authored account of Amerindian bondage was Briton Hammon's Narrative of the Uncommon Sufferings and Surprising Deliverance of Briton Hammon (1760). An enslaved man from Massachusetts, Hammon (c.1720s-after 1776) received his owner's "permission" or order to enlist on a ship trading with the Caribbean. ${ }^{\text {Is }}$ Five months after leaving Boston in December 1747 , his vessel shipwrecked off the coast of Florida. The sole survivor, Hammon was taken captive by a band of Natives. After another five weeks, a Spanish ship rescued him and brought him to Cuba. Here, Hammon served the Spanish governor for several years, interrupted by sixty-seven months in prison for refusing Spanish naval duty. Following his escape on an English warship, he served in the British Royal Navy. Thirteen years after his disappearance, Hammon reencountered his master in England and returned with him to Massachusetts. ${ }^{16}$

The publication of Hammon's autobiography was a premiere in American letters. Its critique of Spanish and Indian bondage at a time when Britain was at war with Spain made the text fit well into different types of captivity account, whose popularity ensured public interest in the text. ${ }^{17}$ As a slave who likely dictated his story to a white amanuensis and whose account was sponsored, if not commissioned, by the author's influential owner, Hammon could exert only a rather limited authorial agency. Nonetheless, publicizing his Narrative gave him access to Boston's Anglo-Protestant print culture and an identity not fully determined by his race and social status.

${ }^{14}$ Mary Louise Pratt, Imperial Eyes: Travel Writing and Transculturation, 2nd edn (London: Routledge, 2008), 9; Weyler, 88.

is Briton Hammon, A Narrative of the Uncommon Sufferings and Surprising Deliverance of Briton Hammon, in Vincent Carretta, ed., Unchained Voices: An Anthology of Black Authors in the English-Speaking World of the Eighteenth Century (Lexington: University Press of Kentucky, 2004), 20-25, 20. On Hammon's status and enlistment see Gagnon, $77-78,82-84$.

${ }^{16}$ Hammon, 20-25; Robert Desrochers Jr., "'Surprising Deliverance'? Slavery and Freedom, Language, and Identity in the Narrative of Briton Hammon, 'A Negro Man'," in Vincent Carretta and Philip Gould, eds., Genius in Bondage: Literature of the Early Black Atlantic (Lexington: University Press of Kentucky, 2001), 153-74, 1 56-58.

${ }_{17}$ Weyler, 77-79, 8I-84. 
Moreover, I view Hammon as a conscious teller of his story. In the opening and closing paragraphs of his text, he engages in a discourse of modesty to assure his readers that he accepted his inferior social status. "My Capacities and Conditions of Life are very low," the narrator claims. He then promises to "only relate Matters of Fact" and leave their interpretation to his socially superior white readers. However, the narrator immediately qualifies his claim to truthfulness, as he admits to presenting the facts "as they occur[ed] to my Mind" and to having "omitted a great many Things." 18 These sentences indicate the active selection and organization of the information Hammon presents to convey his life and labors to white readers. In a similar vein, the Narrative represents a hybrid work steeped in different types of autobiographical genres. In so doing, it stands at the beginning of a specifically African American version of the Amerindian captivity narrative. This narrative mobility, I argue, enabled Hammon and other black authors to claim at least a certain degree of social agency that the Indian captivity format alone would not have provided them with.

Hammon's chronological account of his captivity among a Native band in Florida employs key elements of the Indian captivity genre. Not only did the narrator begin and end his involuntary journey in a white settlement in North America; the rhetoric and title of Hammon's text also emulate a recently published Indian captivity account by a white youth, possibly to place the black man's story in this established framework. ${ }^{19}$ Similarly, Hammon's depiction of his captors represents a common device of the Indian captivity genre to meet readers' desire for sensationalist, exoticizing tales. For example, the narrator's speaking of "sixty Indians in twenty canoes" attacking his ship recalls yet another Indian captivity narrative, likely to evoke the great strength of his captors. ${ }^{20}$ The description of the Amerindians' language and culture further stresses their cultural alterity: the Indians first " $\mathrm{ma}[\mathrm{de}]$ a prodigious shouting and hallowing like so many Devils" and subsequently told the narrator in "broken English ... that they intended to roast [him] alive." ${ }_{21}$ This description powerfully captures the narrator's legitimate fears for his life at the hands of his alien captors. Yet a flawed command of a colonizer's language, a "devilish" appearance, and the specter of cannibalism were also major

${ }^{18}$ Hammon, 20, 24, original capitalization.

19 Ibid., 20-24; John Sekora, "Briton Hammon, the Indian Captivity Narrative, and the African American Slave Narrative," in Jonathan Brennan, ed., When Brer Rabbit Meets Coyote: African Native American Literature (Urbana: University of Illinois Press, 2003), I 4 I-57, I 48-52.

${ }^{20}$ Hammon, 21; Daniel Vollaro, "Sixty Indians and Twenty Canoes: Briton Hammon's Unreliable Witness to History," Native South, 2 (2009), I33-47, I 35, I39-40, 142.

${ }^{21}$ Hammon, 2I-22. 
figures of indigenous "savagery" in captivity narratives and related works of colonial discourse, likely known to Hammon's editors, justifying Native subjugation under white rule. ${ }^{22}$ By using these tropes, the Narrative distinguishes Hammon from his "uncivilized" indigenous captors. As it thus stresses his Christian faith and affinity to English civilization, the text endows Hammon with a narrative authority usually not granted an enslaved black man.

The Narrative strikingly deviates from genre conventions by never revealing the identity of Hammon's indigenous captors. According to Daniel Vollaro, the text's description of the Natives' number, their weapons, speaking some English, and capturing only the ship's sole black sailor suggests that they could have been a slave-raiding party of Creeks or Yamasees. ${ }^{23}$ In the mideighteenth century, many Creek bands were feared throughout large parts of Florida for ravaging the region to capture black fugitives from English slavery for a bounty from the British government. Other bands, in contrast, aligned with the Spanish colonial authorities in Florida and their indigenous allies, including the Yamasees, who protected and even liberated black runaways in the territories under their control. ${ }^{24}$ The fact that Hammon's captors followed him to Cuba and negotiated a release sum with the governor for their former captive suggests that both parties were willing to trade a slave between them. At the time, strong maritime trade networks connected the circum-Caribbean, and the slave trade was at its center. ${ }^{25}$ In contrast, Jeffrey Gagnon views Hammon's captivity as an act of rescue of an enslaved black man by a band of Calusa Indians. This Floridian nation traditionally salvaged shipwrecks off the coast, fought against slavery, and welcomed blacks into their bands to fortify their ranks. Their attack of a sinking English ship, rescuing and sharing meals with a black sailor, and negotiating with the Cuban governor to reclaim Hammon strengthen this view. ${ }^{26}$ Yet neither of the two interpretations can fully account for the portrayal of the Natives in the Narrative,

${ }^{22}$ Vollaro, I4I; Weyler, 92-93; on colonialist discourses of native nations see Robert F. Berkhofer, The White Man's Indian: Images of the American Indian from Columbus to the Present (New York: Vintage, 2004; first published 1979), 25-28.

${ }^{23}$ Hammon, 2 I-22; Vollaro, I 43-44.

${ }^{24}$ Alejandra Dubcovsky, Informed Power: Communication in the Early American South (Cambridge, MA: Harvard University Press, 2016), 6, 194-200; Michele Currie Navakas, Liquid Landscape: Geography and Settlement at the Edge of Early America (Philadelphia: University of Pennsylvania Press, 201 8), 6.

${ }^{25}$ Hammon, 22; Elena A. Schneider, The Occupation of Havana: War, Trade, and Slavery in the Atlantic World (Williamsburg, VA and Chapel Hill: Omohundro Institute of Early American History and Culture and University of North Carolina Press, 2018), I-3, 8, 37-39, 64-66.

${ }^{26}$ Hammon, 2 I-22; Gagnon, "They Us'd Me," 74-76, 84-93; on the Calusas see Navakas, 6. 
and this may well have been intended. As an enslaved man addressing a potentially pro-slavery audience, Hammon could neither criticize indigenous slave raiders in British service nor mention Native slave rescuers. Moreover, as their identity remains opaque, Hammon's captors appear exclusively as indigenous cultural - rather than racial-others. This allows the black narrator to distinguish himself from them and claim the identity of a Christian Englishman.

This function of the Natives is echoed in Hammon's subsequent portrayals of Spanish Cuban society in his Narrative. Keith Michael Green points out that the text "implicates multiple genres and geographies of unfreedom," addressing black and Native servitude in Massachusetts, Indian captivity in Florida, Spanish imprisonment in Cuba, and naval service in the Atlantic. ${ }^{27}$ This blend of incidents embeds Hammon's Narrative in the older but continuing tradition of British narratives of exploration that reported on a series of captivities in foreign lands. These not only tended to include accounts of shipwrecks but also to compare indigenous bondage and confinements by rival colonial powers. Well-known examples of this body of writings include "A Discourse Written by one Miles Philips[,] Englishman," which appeared in Richard Hakluyt's Principal Navigations (1589/1600) and records Philips's experiences in the Spanish West Indies, or the disbanded soldier Peter Williamson's popular French and Indian Cruelty (1757) about his indigenous bondage and French war captivity. ${ }^{28}$ Hammon's piece further anticipates black transatlantic slave and Barbary captivity narratives such as The Interesting Narrative of the Life of Olaudah Equiano (1789) or The Narrative of Robert Adams (1816), whose authors followed Hammon in claiming, respectively, English and American identities in their texts. ${ }^{29}$

In light of the ongoing French and Indian War, it is not surprising that echoing the French Army in Williamson's account ${ }^{30}$ - Spanish Cuba appears in Hammon's Narrative as almost as "savage" as indigenous Florida before. As Hammon was most likely enslaved by the Spanish governor, his description

${ }^{27}$ Green, Bound to Respect, 5-6.

${ }^{28}$ Miles Philips, "A Discourse Written by One Miles Philips Englishman, One of the Company Put on Shoare Northward of Panuco, in the West Indies by M. John Hawkins 1568," in Richard Hakluyt, ed., The Principal Navigations, Voyages, Traffiques, and Discoveries of the English Nation (Ann Arbor: Text Creation Partnership, 20 I I; first published 1599-1600), 469-87; Peter Williamson, French and Indian Cruelty, Exemplified in the Life and Various Vicissitudes of Fortune of Peter Williamson (Edinburgh, 1792).

29 Olaudah Equiano, The Interesting Narrative of the Life of Olaudah Equiano, or Gustavus Vassa, the African, Written by Himself, ed. Werner Sollors (New York: Norton, 200I); Robert Adams, The Narrative of Robert Adams, a Barbary Captive, ed. Charles Hansford Adams (New York: Cambridge University Press, 2005).

30 Williamson, 87-91. 
echoes slaveholding practices in mid-eighteenth-century Cuba, where especially household slaves enjoyed greater personal opportunities and freedom of movement. Although Hammon was treated well in Cuba, he was confined to the island. His Narrative presents his life there as a series of coercions by the civic, military, and religious powers of colonial Spain. The narrator expounds on the display of wealth and power of Spanish Catholicism he observes when hired out to the Bishop of Havana, and he indicts the brutality of martial law when recounting his imprisonment "in a close Dungeon" for refusing Spanish naval duty. ${ }^{\text {I }}$ Anticipating the British consul purchasing Robert Adams's freedom in North Africa, Hammon reports being rescued from prison and servitude in Cuba by two "true" Englishmen who acknowledge the black captive as "an Englishman under English Colours." ${ }_{22}$ If this description is accurate, it is rather unusual, as white English people at the time viewed most blacks not as their peers but "as property or criminals." ${ }_{33}$ It thus seems more likely that Hammon's rescue through English interventions functions in the Narrative once again to replace racial distinctions with cultural ones, as the text pits English Protestantism and liberation against Spanish Catholicism and colonialism. Echoing Williamson's army enlistment in the French and Indian War and anticipating Equiano's maritime servitude, ${ }^{34}$ Hammon's pamphlet renders his labors visible to present himself as a brave mariner and loyal British subject, two roles not available to him in a "pure" Indian captivity narrative but crucial for buttressing his claim to Englishness.

Hammon's depiction of his Indian and Spanish captivity finally questions the form of bondage Hammon's Narrative never renders explicit: black chattel slavery in British North America. As an enslaved man in Massachusetts, Hammon could not openly critique slavery in his text or present his return as anything but voluntary, although it was likely triggered by poverty or fear of recapture. ${ }^{35}$ However, as his text repeatedly presents Hammon as a Protestant Englishman and his Amerindian and Spanish bondage as both illicit and benign, the Narrative suggests that Hammon's enslavement in Massachusetts could be similarly illegitimate and his treatment even worse. The narrative mobility of this hybrid text and its foreign settings thus enabled Hammon to claim an identity not defined by his race and status and thus to discursively defy his ongoing bondage.

\footnotetext{
${ }^{31}$ Hammon, 22-23, 25 n. 19; on Cuban slavery see Desrochers, "Surprising Deliverance," I 56-58; Green, 3; Schneider, I I, 77.

33 Weyler, Empowering Words, i 9.

${ }^{32}$ Hammon, 23; Adams, 65.

35 Desrochers, 159-60.
} 


\section{CAPTIVITY AND CONVERSION IN THE NARRATIVE OF JOHN MARRANT}

While Hammon's autobiography only saw a single printing and seems not to have found much resonance in subsequent black writing on Indian captivity, John Marrant's A Narrative of the Lord's Wonderful Dealings with John Marrant, a Black (1785) became one of the most popular examples of the captivity genre. ${ }^{36}$ A free black from New York, Marrant (1755-9I) grew up in different southeastern colonies, where he was apprenticed to a musician and a carpenter. Rejected by his family when he converted to Methodism, he left home at the age of fourteen and was rescued by a Cherokee hunter, who brought him to his village. According to his Narrative, the tribe arrested Marrant and sentenced him to death but released him when his prayers converted their chief and other members of the tribe. Marrant spent two years among his former captors before returning to his family. After the Revolutionary War, he moved to England, where the Countess of Huntingdon became his patron. He was ordained as one of the first black Protestant ministers in the country and subsequently deployed as a missionary to black communities in Nova Scotia, Canada. ${ }^{37}$ During his ordination in May 1785 , he delivered an oral account of his life that was to become the basis of his autobiography. Two months later, the white Methodist minister William Aldridge published a written version of the story in London. With the fourth edition of the book, which he had enlarged and overseen himself, Marrant claimed full authorship of his manuscript. ${ }^{8}$ The text became an instant success and was reprinted across Britain, Ireland, and Canada, though not in the United States until I 820, most likely because of its call for black spiritual equality, its critique of slavery, and its lack of anti-indigenous sentiments. ${ }^{39}$

Marrant's Narrative has been widely analyzed as an Indian captivity narrative, even though scholars also point out its role as a spiritual autobiography. ${ }^{40}$ What is less frequently discussed is the role of the book, like Hammon's

${ }^{36}$ Henry Louis Gates Jr., The Signifying Monkey: A Theory of African-American Literary Criticism (New York: Oxford University Press, 1988), i 57.

37 John Marrant, A Narrative of the Lord's Wonderful Dealings with John Marrant, a Black, in Adam Potkay and Sandra Burr, eds., Black Atlantic Writers of the Eighteenth Century: Living the New Exodus in England and the Americas (Basingstoke: Macmillan, 1995), 75-105; Michelle Burnham, Captivity and Sentiment: Cultural Exchange in American Literature, 1682-1862 (Hanover, NH: University Press of New England, 1997), 125-26; Benilde Montgomery, "Recapturing John Marrant," in Brennan, When Brer Rabbit Meets Coyote, I $58-67,158,162$.

${ }^{38}$ Weyler, 98-99, 104.

39 Burnham, I25; Gates, I 57; Weyler, i05.

$4^{\circ}$ See, e.g., Burnham; Montgomery; Weyler; Tiya Miles, “'His Kingdom for a Kiss': Indians and Intimacy in the Narrative of John Marrant," in Ann Laura Stoler, ed., Haunted by 
pamphlet, as a hybrid text that consciously intertwines the two genres. Like Hammon's, Marrant's memoir further engages in this act of narrative mobility to establish the narrator as a Protestant Christian preacher and thus assert his claim to discursive authority and social agency widely denied black men in his days. Probably the most pivotal moment in Marrant's account, which most crucially blends the two autobiographical genres, is the young carpenter's experience of Cherokee captivity. What is most striking about this incident as told in Marrant's text is that the narrator, although threatened with torture and execution, was spared this fate and, even more, able to convert his captors to Christianity. In a similar vein, the Cherokee never seem to intend to enslave their black captive ${ }^{41}$ At the time of Marrant's captivity, the tribe was known for its rigid regime of African slavery. ${ }^{42}$ His captors may have refrained from enslaving Marrant because they acknowledged his friendship with a tribal member as a form of kinship entitling him to protection. Their threat of torture and execution thus might have been part of an initiation ritual to formally integrate the black youth among their band. ${ }^{43}$ However, Marrant's depiction of his time among the Cherokee in the mold of an Indian-captivity-turned-Indian-conversion account in his Narrative may equally represent a narrative strategy. It dramatizes his emergence as a Methodist preacher, renders his missionary labors visible, and thus justifies his claim to belonging to the "evangelical empire" of white-dominated Protestant missionary and print cultures. ${ }^{44}$ The fact that "the form of torture and execution" that Marrant's narrator was to meet does not reflect Cherokee but Iroquois practices and that it "appears throughout Indian captivity narratives" supports the interpretation that this episode was meant to fit widely recognizable literary genre conventions rather than accurately testify to Marrant's experiences. ${ }^{45}$ As Weyler argues, "the always popular captivity genre was crucial in enabling men who would otherwise have been culturally invisible to become visible." 46 In Marrant's case, embedding an Indian captivity narrative within his spiritual autobiography functions to transform a powerless black adolescent into a Methodist preacher who claims authority and agency.

What is crucial here is that the Cherokee episode of the Narrative is not detached from the spiritual autobiography surrounding it, but both genres

Empire: Geographies of Intimacy in North American History (Durham, NC: Duke University Press, 2006), I63-88.

${ }^{41}$ Marrant, 84-87.

42 Bartl, "Native American Tribes," 163-67; Green, Bound to Respect, 69-72; Krauthamer, Black Slaves, 17-19, 28.

${ }^{43}$ Merritt, At the Crossroads, 53, 55, 294-95, i 80; Tiya Miles, "Uncle Tom Was an Indian: Tracing the Red in Black Slavery," in Natalia Molina, Daniel Martinez HoSang, and Ramón A. Gutiérrez, eds., Relational Formations of Race: Theory, Method, and Practice (Oakland: University of California Press, 2019), I 2 I-44, I $28-29$.

44 Weyler, 19, 77, I13. $\quad{ }_{45}^{45}$ Marrant, editor's comments, ioo n. $32 . \quad{ }^{46}$ Weyler, 84. 
are interwoven here. In line with the conventions of spiritual autobiography, Marrant's narrator invokes biblical examples such as Daniel's deliverance from the lion's den and St. Paul's preaching in captivity to frame Marrant's experiences among the Cherokee as God's trial of his faith and endorsement of his spiritual calling. ${ }^{47}$ As Benilde Montgomery argues, the emphasis on a religious interpretation of captivity further connects the episode to seventeenth-century Puritan captivity narratives such as Mary Rowlandson's The Sovereignty and Goodness of God (1682) rather than to the secular captivity texts prevalent in Marrant's time..$^{48}$ Tying Marrant's Indian captivity to his Christian spirituality was an important strategy that enabled the black carpenter to obtain discursive agency usually denied a man of his race in eighteenthcentury North America. At the time, Zafar observes, "Black men ... had ... to describe themselves not as black men, but as other kinds of men - as religious seekers, as adventurers, as fledgling capitalists." 49 Where Hammon had used his indigenous captivity as a foil to critique Spanish slavery and assert his Englishness, Marrant blended the Amerindian captivity genre and the spiritual autobiography in his Narrative to showcase his missionary credentials as a basis for claiming the identity and authority of a black Methodist preacher in the white-dominated transatlantic evangelical missionary network.

Marrant achieves this goal in his memoir through an act of triple transformation. First, his conversion to Methodism a year before his captivity establishes him as an evangelical Christian and thus as a plausible witness in the eyes of his white readers. Second, by converting his indigenous captors to Christianity, Marrant's narrator confirms the "superiority" of the Christian faith over Amerindian belief systems, and he fashions himself, as Weyler observes, as

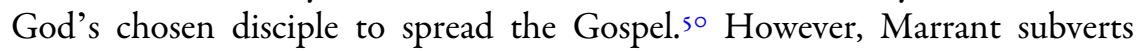
the ideology of the white "civilizing mission" connected to Protestant Christianization efforts among indigenous nations in North America, as his narrator does not attempt to further change his captors' lifeways. Instead, he transforms himself into a Cherokee by mastering the nation's language, adopting tribal customs, and serving as a spiritual leader among the band. Marrant's Narrative conveys this most powerfully in an image of clothes exchange. While the black narrator "assumed the habit of the country, and was dressed much like the king" of the Cherokee, the actual chief "would

${ }^{47}$ Marrant, 84, 100 n. 33; Sandra M. Gustafson, Eloquence Is Power: Oratory and Performance in Early America (Chapel Hill: University of North Carolina Press, 2000), 102.

${ }^{48}$ Mary Rowlandson, The Sovereignty and Goodness of God, in Sayre, American Captivity Narratives, 137-75; Montgomery, I 59-6I.

49 Zafar, We Wear the Mask, 56.

so Weyler, 108-10, 255 n. 103. 
take off his golden ornaments ... like a child." ${ }_{51}$ "Becoming Indian" by integrating into an indigenous nation was possible because eighteenth-century European colonizer, black, and Cherokee societies understood racial identity as being potentially mutable, depending on cultural and environmental circumstances. Like other indigenous nations, the Cherokee permitted blacks usually slaves - to join their ranks. ${ }^{52}$ Adopting a Cherokee identity thus enabled Marrant to "undo" his blackness. This represented an upward social movement, as his English target readers closely associated blacks with slavery, whereas they viewed Amerindians as "savages" yet able to attain a certain "nobility." 53

While Marrant adopted Cherokee culture, he crucially maintained his Christian faith. Even more, he mobilized his belief and oratory skills to further transcend social barriers and assert his identity as a Methodist missionary. According to Sandra Gustafson, oral speech enjoyed a high prestige as the most authentic form of verbal expression in eighteenth-century North America. This applied especially, and in similar ways, to indigenous belief systems in which charismatic oratory played a major role and to the evangelical Christian understanding of "divine power operating through the spoken word." 54 Marrant, who may have personally encountered indigenous eloquence among the Cherokee, used this resemblance to his advantage to regain his liberty from captivity and claim his new role as a Christian missionary. A key scene in his Narrative twists the trope of the talking book, which presents literacy and written language as markers of power and "culture" in both European colonial discourse and the black slave narrative.5s In Marrant's account, it is the black carpenter whose ability to understand the Bible places him in a position of power and knowledge inaccessible to his Cherokee captors. Tellingly, it was not a silent reading but the spoken word-Marrant's reciting Scripture and praying aloud in the Cherokee tongue - that moved his captors to set him free and accept his faith and leadership. While the Cherokee may have adopted Christianity, it is equally likely that they merely accepted Marrant as one among several spiritual authorities or that they feared his mysterious powers. ${ }^{66}$ Nevertheless, their "conversion" remains an important point in Marrant's argumentation. His acculturating

${ }^{51}$ Marrant, 87; on the "civilizing-mission" ideology see Lori J. Daggar, "The Mission Complex: Economic Development, 'Civilization,' and Empire in the Early Republic," Journal of the Early Republic, 36 (Fall 2016), 467-91.

52 Miles, "Uncle Tom Was an Indian," I 29-30; Katy L. Chiles, Transformable Race: Surprising Metamorphoses in the Literature of Early America (New York: Oxford University Press, 2014), 3, I IO, I 2 I-25.

53 Miles, "His Kingdom for a Kiss," 165-73, 178-80. 54 Gustafson, I05.

ss Gates, The Signifying Monkey, I 59-61; Miles, "His Kingdom for a Kiss," I 80-8 I.

${ }_{56}$ Marrant, 85-87; Gustafson, 103-5; Weyler, 107, 255 n. 103. 
to Cherokee life while simultaneously asserting his religious and rhetorical superiority over the tribe leaves white claims to power and authority unchallenged yet enables Marrant to transcend racial barriers and establish himself as a Methodist missionary.

The social mobility and agency entailed in the way Marrant transforms himself and his Cherokee captors crucially deviate from patterns of (im)mobility and powerlessness characterizing white-authored Indian captivity narratives. The latter body of texts often presents indigenous bondage as a singular rupture in the captives' life, manifest in the combination of physical confinement and enforced nomadism, which the captives fiercely resisted and sought to escape from. In contrast, Marrant's Narrative presents the narrator's Cherokee captivity as one of several pivotal moments that lead him toward religious salvation entangled with upward social mobility. Like Hammon's account, Marrant's volume powerfully captures the life-changing experiences of a young black man in a hybrid text form of a North American Indian captivity story woven into another type of memoir. As Marrant's Narrative affirms both the Indian captivity narrative and the spiritual autobiography, it capitalizes on their ongoing popularity among English audiences, especially evangelical readers. As the book undermines the two genres, it opens a space for black social agency, as it conveys the former carpenter's labors to his white readers and thus enables Marrant to claim his place, hitherto widely denied a man of his race and class, as a Methodist missionary.

\section{AMERINDIAN SLAVERY IN THE LIFE AND ADVENTURES OF HENRY BIBB}

A similar transformation of a black life via an episode of Amerindian bondage occurs in Henry Bibb's autobiography, Narrative of the Life and Adventures of Henry Bibb, an American Slave (1 849). Bibb ( 18 I 5-54) was born and raised as a slave in Kentucky. Although he succeeded in running away to Ohio in 1837 , he would move back and forth between free and slave states, as he attempted to rescue his enslaved wife and daughter. After Bibb was recaptured in I 839, he passed through the hands of several owners, including a Cherokee in the Indian Territory (now Oklahoma). Bibb escaped to freedom after the death of his indigenous master in $184 \mathrm{I}$. Based in Detroit and later in Sandwich, Canada, he would work as an abolitionist orator and agent on the Underground Railway and subsequently edit Canada's first black newspaper. ${ }^{57}$

57 Afua A. P. Cooper, “'Doing Battle in Freedom's Cause': Henry Bibb, Abolitionism, Race Uplift, and Black Manhood, I 842-1854," PhD dissertation, University of Toronto, 2000 
In I 849, Bibb's autobiography appeared to favorable reviews in the antislavery press and became an instant best seller. The volume draws on the author's oral accounts of his life on the abolitionist lecture circuit. ${ }^{8}$ Bibb's identification as "an American slave" marks his Life and Adventures as representative of the African American slave narrative. This type of black-authored autobiography testifies to the conditions of black chattel slavery to inspire abolitionist sentiments and action among its white target audience. Like Indian captivity stories, slave narratives also required white editors to authenticate the identity of their black authors and the truth of their accounts.99 This has led Andrews to criticize Bibb for having "acquiesced in the power of white men" with his account. ${ }^{60}$ However, as he penned his own story, Bibb exerted greater control over his text than the black authors of as-told-to autobiographies such as Hammon or Marrant. Moreover, I argue that it was by largely adhering to certain conventions demanded by his white sponsors and audiences that Bibb was able not only to publicize his story but also to individualize it within the confines of the genre.

One way in which Bibb's Life and Adventures bends genre conventions is the text's appropriation of the Indian captivity narrative and its integration into a black slave narrative. The latter adopted from the captivity genre the plot structure and rhetoric of a protagonist's captivity in and escape from a hostile environment. In doing this, the slave narrative capitalized on white readers' empathy for the victims of indigenous capture. This enabled formerly enslaved African Americans to convey black labor and experiences of bondage to white audiences, gain the acceptance of these readers as credible witnesses to the ills of slavery, and elicit their support for anti-slavery actions. ${ }^{61}$ In contrast to many other slave narratives, Bibb's account does not depict a linear sociospatial path from southern servitude to northern freedom. Instead, its circular pattern of Bibb's escapes from and returns to slavery, his itinerant rather than stationary life, and his removals through unfamiliar southern territories evoke further elements of the Indian captivity narrative. Unlike the victims of indigenous raids, the fugitive Bibb did not face an unfamiliar situation when he was hunted and seized by slave catchers. Yet his narrative repeatedly portrays white slave hunters as ferocious creatures mercilessly chasing their prey. This

(TSpace Repository, University of Toronto Library, 2008), at http://hdl.handle.net/ 1 $807 /$ 14503; Charles Heglar, Rethinking the Slave Narrative: Slave Marriage and the Narratives of

Henry Bibb and William and Ellen Craft (Westport, CT: Greenwood Press, 2001), 26, 33 , $4 \mathrm{I}-42$.

${ }^{58}$ Henry Bibb, The Life and Adventures of Henry Bibb, an American Slave, ed. Charles Heglar (Madison: University of Wisconsin Press, 2000); Cooper, I 27-28, I40.

59 Bus, "Lost and B/Found," 80, 82-83; Heglar, 9-1 I, 36, 38-39.

60 Andrews, To Tell a Free Story, 106-7.

${ }^{61}$ Bus, 76-77; Zafar, We Wear the Mask, 68-69. 
depiction draws on white images of indigenous raiders of white settlements as animal-like nomads without "civilization." ${ }^{62}$ Moreover, the narrator admits after one of his recaptures, "I was to be sold in the Louisville slave market, or in New Orleans, and I never expected to see my family again." ${ }^{63}$ In stressing his attachment to his family and his anxiety of separation through capture and enforced relocation by "savage" slave hunters, he draws upon plot devices and discourses of indigenous "savagery" and the Indian captivity narrative to elicit sympathy for his plight.

Similarly, Bibb's depiction of his bondage to a Cherokee in The Life and Adventures simultaneously endorses and deviates from the captivity genre and its foundational belief in indigenous societies' lack of "civilization." Purchased as a slave by an individual Cherokee rather than being captured by an entire tribal band, Bibb largely presents his life in Indian country through the lens of the slave narrative. His memoir contributes to the popular view that black slavery among indigenous nations was more benign than under white masters. ${ }^{64}$ By the time of Bibb's servitude, slavery had been an established practice among the Cherokee, and when the tribe was forced to relocate to the Indian Territory on the Trail of Tears in 1836 , slaveholding members took their human property along. Enslaved people were an important labor force in Cherokee agriculture, although mainly members of the tribal elite kept plantations. To organize bound labor, the Cherokee, like white slaveholders, issued slave codes, employed overseers, and separated enslaved families. ${ }^{65}$

In his Life and Adventures, Bibb admits that his indigenous owner possessed "a large plantation and quite a number of slaves." Yet the narrator denies that this man or other Cherokee practiced either capitalism or race-based social stratification. In contrast, he claims that "the Indians ... have no overseers to whip or drive [slaves] ... They have neither slave laws nor negro pews ... [and neither] separate husbands and wives, nor parents and children." Furthermore, subverting white views of Amerindians as impulsive and irrational, Bibb's narrator affirms that his Cherokee master "was the most reasonable and humane slaveholder that I have ever belonged to." ${ }^{66}$ Bibb held a relatively privileged position as a light-skinned, well-treated manservant to his Cherokee owner, which contrasts with his earlier life under the lash of white

${ }^{62}$ Bibb, 6I, 64, I28-30; on imagery of indigenous people see Berkhofer, The White Man's Indian, 28-30, 72-80.

${ }^{63} \mathrm{Bibb}, 69$.

${ }^{64}$ Ibid., I 52-53; on the trope of "benign slavery" see Bartl, "Native American Tribes," I6364; Green, Bound to Respect, 68, 74-77.

${ }^{65}$ Green, 66-74; Krauthamer, Black Slaves, 8, 40, 43; Kathleen DuVal, The Native Ground: Indians and Colonists in the Heart of the Continent (Philadelphia: University of Pennsylvania Press, 2006), 215, 217-18, 242. 
slaveholders. ${ }^{67}$ Yet this only partially accounts for his benign portrayal of indigenous bondage. This depiction, I argue, functions as a foil to the white institution, its cruel treatment of the enslaved, their economic exploitation, and their material neglect. Like many other slave narratives, Bibb's account further emphasizes the piety of enslaved people and contrasts it with the physical abuse and spiritual oppression by self-appointed Christian white masters. As Weyler argues, "professing Christianity was one means for ... slaves ... to incorporate themselves into the English-speaking community." 68 In the context of his indigenous bondage, Bibb's narrator reinforces this critique by suggesting that serving a "heathen" Cherokee was a lesser evil. "If I must be a slave," he asserts, it should "rather be ... to an Indian, than to a white man." 69

Immediately after this statement, however, Bibb draws on the white colonial discourse that framed the cultural alterity of indigenous nations as fundamentally lacking "civilization," to establish his own civility in contrast to his Cherokee captors. Bibb's narrator presents the Cherokee participants in an "Indian dance or frolic" as far removed as possible from Anglo-American standards of propriety. Underlining the notion of indigenous people as animal-like creatures, the narrator states that the Cherokees wore animal dress pieces, danced wildly. They also deviated from Protestant principles as they engaged in "degrading practice[s]" like gambling, fighting, and drinking during the festivities. ${ }^{\circ}$ Such tableaux of exotic otherness were a staple of Indian captivity narratives and related works of colonial discourse that sought to justify white settlement and indigenous dispossession across North America. ${ }^{71}$ Similarly, the purportedly deficient culture of the "half-civilized tribes" Bibb encounters when he flees from the Cherokee manifests itself in stereotypical images of indigenous otherness: simple but lethal indigenous weapons, red facial paint, and exotic Native dress. Taking up the motif of the unintelligible Native also displayed in Hammon's text, Bibb's narrator further complains about one of these bands that "not one [person] could talk or understand a word of the English language." 72 Presenting the Amerindians as culturally inferior "savage" others and fashioning himself as their captive-turning-fugitive legitimizes the narrator's escape from slavery

67 Ibid., I I - -2 I, I 3 I-34, I 52-53; Green, 77-80.

68 Weyler, Empowering Words, 93; on narrations of slave piety see Ted Bailey, "Portraits of Piety: Authenticating Strategies in Slave Narratives and Two Antebellum AfricanAmerican Novels," The AnaChronisT, I4 (2009), 47-66, 50-51.

$69 \mathrm{Bibb}, \mathrm{I} 53$; for his critique of religious white slaveowners see $86-87$, I I O-I 2, I 20, I 30.

70 Ibid., I 53 .

72 Bibb, i 56 ; see also i 58. 
and enables him to appropriate the stance of white Anglo-Protestant civility pious, abstinent, and self-disciplined.

This concept of civility was further tied to a notion of patriarchal manliness usually denied enslaved black men in white America, thus barring them from protecting and providing for their families..$^{33}$ As Sarah Roth points out, slave narratives of the i 840 s advocated an ideal of black manliness based on a "noble" endurance of suffering that allowed the narrators to claim male authority without raising white audiences' fears of black violence. Even one of the most famous examples of individual physical resistance, Frederick Douglass's fight with the "slave-breaker" Edward Covey in his Narrative of the Life of Frederick Douglass (1845), carefully frames the black youth's defiance as an act of inner liberation through his somewhat restrained defiance of brutal force. ${ }^{74}$ In a similar vein, Bibb's Life and Adventures voices this understanding of manliness in placing the black fugitive's recurrent attempts to rescue his wife and child at the center of his story, and in advocating "the art of running away" as his mode of rebellion.75 A key scene from his flight from the Cherokee draws explicitly upon white readers' dread of Indian attacks to point out the racial double standard at work in their criminalizing black fugitives from slavery. The narrator asks,

If a white man had been captured by the Cherokee Indians and carried away from his family for life into slavery ... would it be a crime for the poor fugitive, whose life, liberty and future happiness were all at stake, to mount any man's horse ... to effect his escape? Or who would not do the same thing to rescue a wife, child, father, or mother? ${ }^{7}$

In this passage, Bibb does not state black equality to white Americans. Yet, as he reveals white responses to Indian captivity to be no different from his behavior as a fugitive slave, he demands to be judged according to the same moral and legal standards as a white man.

The Life and Adventures of Henry Bibb was written as a black slave narrative. Yet, by integrating elements of the Indian captivity narrative into this text, the narrator holds up a mirror to white complacency with slavery, especially by professed Christian slaveholders. Through his account of his life among and flight from the Cherokee, he fashions himself as a "civilized" husband and father threatened by "savage" (re)capture and bondage. The narrative mobility of his hybrid slave and captivity narrative thus enables Bibb to transcend the

${ }^{73}$ Green, 94-95.

${ }^{74}$ Sarah N. Roth, “'How a Slave Was Made a Man': Negotiating Black Violence and Masculinity in Antebellum Slave Narratives," Slavery and Abolition, 28, 2 (Aug. 2007), 255-75, 261-64; Frederick Douglass, Narrative of the Life of Frederick Douglass, an American Slave, Written by Himself, with introduction by Robert Stepto (Cambridge, MA: Harvard University Press, 2009), 76-79.

75 Bibb, I5.

${ }^{76}$ Ibid., 163. 
social boundaries of the fugitive-slave autobiography and claim the defiant, patriarchal manliness as well as the freedom and social agency usually reserved for white men.

\section{CAPTIVITY AND INTEGRATION IN THE LIFE AND ADVENTURES OF JAMES BECKWOURTH}

Bibb's use of the Indian captivity narrative ties in with the emergence of a new body of texts recounting indigenous captivity in the North American West, following the enforced removal of eastern Native nations to the Great Plains region. ${ }^{77}$ The black mountain man James Beckwourth's (1798/1 80066) The Life and Adventures of James P. Beckwourth (1856) is the bestknown black-authored autobiography that draws upon this genre. Beckwourth was born into slavery in Virginia but moved to Missouri with his slave-owner father's family as a child. Acknowledged and manumitted by his father in 1824, he joined the Rocky Mountain Fur Company to explore territories in the northern plains and the Rocky Mountains, trap beaver, and trade with indigenous nations. In the winter of $1825-26$, he was captured and adopted by a band of River Crow Indians, among whom he would live as a warrior and trader for thirteen years. He subsequently worked in various professions and places in the American West but also served the United States forces in the Indian Wars against the Seminoles in Florida in 1837 and different Plains Indian nations in $1864 .{ }^{78}$

Although he was literate, Beckwourth engaged the white confidence man, Justice of the Peace, and journalist Thomas Bonner to pen his memoir. Published in 1856, his Life and Adventures became an instant success but also aroused controversy over the author's boasting, factual inaccuracies, and passing for white. ${ }^{79}$ The volume narrates the life of its protagonist until the early i 850 , focussing especially on his life as a trapper, trader, and Crow warrior in the 1820 s and 1830 s. It also integrates passages of ethnographic observation about different Native nations, thereby establishing Beckwourth as an expert on Plains Indian cultures. In his preface, Bonner claims to have penned Beckwourth's story without any editorial intervention. ${ }^{8 \circ}$ However,

Arnold Krupat, "American Autobiography: The Western Tradition," Georgia Review, 35,2 (Summer 1981), 307-17, 310.

${ }^{78}$ James P. Beckwourth, The Life and Adventures of James P. Beckwourth, as Told to Thomas D. Bonner, ed. Delmont R. Oswald (Lincoln, NE: Bison Books, I98 I); Elinor Wilson, Jim Beckwourth: Black Mountain Man and War Chief of the Crows (Norman: University of Oklahoma Press, i 988).

79 Wilson, 5-7, 18, 52, 196; Delmont R. Oswald, "Introduction," in Beckwourth, vii-xiii, vii-xi.

${ }^{8 \circ}$ Beckwourth, 4 . 
like other dictated black autobiographies, the book not only caters to the tastes and agendas of white readers but also speaks with a composite voice that is "implicated in cross-cultural complications and contradictions." ${ }^{8}$ The elaborate language, European cultural references, and use of genre conventions indicate Bonner's influence on the text, ${ }^{82}$ while certain mannerisms can be traced to the black author, and the exaggerations of his adventures are typical of nineteenth-century western American borderlands narratives. ${ }^{83}$ As a freeman who had selected his amanuensis and authorized his manuscript before publishing, ${ }^{84}$ Beckwourth moreover enjoyed a considerable agency over his public narrative.

Like Hammon, Marrant, and Bibb, Beckwourth achieved his mobility and agency by making his narrative use and modify popular autobiographical formats. The text type of the western borderlands autobiography blends narrative genres, such as the picaresque novel, Indian captivity narrative, frontier romance, and western "tall tale." Often dictated to amanuenses, these works of writing tell the stories of nonindigenous trappers, traders, scouts, and hunters of the Great Plains and the Rocky Mountains as heroic tales of individual exploits in travel, trade, and Indian warfare. Paving the way for the American commercial expansion into the West, western borderlands autobiographies fulfilled readers' desire for information about the region and their dream of an adventurous life away from social constraints. At the same time, they voice loyalty to white civilization and justify their protagonists' contributions to the violent removal and genocide of the Plains Indian nations as "the inevitable triumph of civilization over savagery." ${ }_{5}$

As a western borderlands autobiographer, Beckwourth's narrative authority rested on his coming across as a representative mountain man. A key component of this self-fashioning is his life as a Crow warrior, and his reworking elements of the Indian captivity narrative to explain how he came to join the tribe. The ongoing threat of Amerindian raids in the West kept captivity narratives resonant with American readers. For authors of the genre, in turn,

${ }^{81}$ Noreen Grover Lape, West of the Border: The Multicultural Literature of the Western American Frontiers (Athens: Ohio University Press, 2000), 24-25. I use the term "borderlands" rather than the politically fraught "frontier" here to convey the West's role as a sociocultural contact zone of diverse populations. See Jeremy Adelman and Stephen Aron, "From Borderlands to Borders: Empires, Nation-States, and the Peoples in Between in North American History," American Historical Review, 104, 3 (June 1999), 8 I $4-4$ I, 8I 5 .

${ }^{82}$ Lape, 23-24; Judith Madera, Black Atlas: Geography and Flows in Nineteenth-Century African American Literature (Durham, NC: Duke University Press, 2015), 90-91.

${ }^{83}$ Wilson, 6r; Krupat, 3 ro.

${ }^{84}$ Delmont R. Oswald, "Epilogue," in Beckwourth, 603-28, 604.

${ }^{85}$ Krupat, 3 1 4, also, 309-13; Lape, 23, 27, 36. 
"captivity was important, because ... it offered an alibi for transculturation, an assurance against cultural regression, and thereby credibility with mainstream readers." ${ }^{66}$ The Life and Adventures specifically presents Beckwourth's initiation into the Crow nation as a captivity-cum-adoption procedure. ${ }^{87}$ Like other Plains Indian societies, the Crow adopted captives into their bands to replace lost members and strengthen their numbers. Moreover, as trade relations between the Crow and the United States intensified from the midI 820 s, a growing number of nonindigenous trappers lived among Crow bands, and some of them even became full tribal members. ${ }^{88}$ In Beckwourth's narrative, his adoption is prepared by a white trapper's tale that his black colleague was a Crow who had been stolen as an infant and raised among whites. The Crow likely knew that this story had been fabricated to install Beckwourth among them to mediate between their band and white traders. ${ }^{89}$ Yet, in his narrative, the tale functions to establish Beckwourth as a cultural superior to his captors who remained loyal to American hegemonic culture despite his quick and full integration into indigenous society.

Following a key motif of Indian captivity narratives, Beckwourth describes in his text how his captors took him by surprise, marched him to their camp, and held him under guard there. A subsequent scene in which several Crow women inspect Beckwourth's body evokes similar scenes of physical examination in Indian captivity and black slave narratives to convey the anxiety this procedure induced in the black captive to his white readers. In both slave and captivity narratives, such passages usually foreground the dehumanization of the person held in bondage. Beckwourth's Life and Adventures, however, subverts this convention. Here, the Crow women's examination does not lead to Beckwourth's toil in servitude but his identification with a tribal leader's lost son, which lays the basis for his subsequent career as a Crow warrior. $9^{\circ}$ Like Marrant's transformation into a Cherokee more than fifty years earlier, Beckwourth's adoption by the Crow thus functioned to render his blackness invisible. Without challenging white hegemony, this socially upward move to a less maligned racial identity category liberated Beckwourth from the social constraints imposed on black men at the time.

Although he lived freely among the Crow for thirteen years, Beckwourth's memoir follows the tradition of the captivity narrative in stressing his unbroken identification with American culture toward his readers. Like Hammon's, Marrant's, and Bibb's accounts, his Life and Adventures follows

${ }^{86}$ Sayre, "Introduction," I 4.

${ }^{87}$ Beckwourth, I 45-50.

88 Paul H. Carlson, The Plains Indians (College Station: Texas A \& M University Press, 1998), 48; Frederick E. Hoxie, Parading through History: The Making of the Crow Nation, I8051935 (New York: Cambridge University Press, 1995), 53-54, 57, 61-67, 70-71, 78.

${ }^{89}$ Beckwourth, 139-4I; Wilson, 48-49, 60-6I.

90 Beckwourth, I $45-48$. 
white views of Native societies as animal-like "savages" and/or immature "children of nature." As agriculture and subordination to white rule functioned as markers of civility, nomadic hunter and warrior cultures like the Crow were seen as particularly lacking "civilization." ${ }_{91}$ To distinguish himself from his Crow environment, Beckwourth's narrator emphasizes his superior intellect, entrepreneurial spirit, Christian faith, and abhorrence of violence. For example, he condescendingly asserts to have consented to live among the Crow out of pity and economic calculation. "I could not find it in my heart to undeceive these unsuspecting people," he states. Moreover, by joining the tribe, he could "trap in their streams unmolested, and derive more profit under their protection." ${ }_{92}$ Beckwourth thus aligns with the other black authors in using Amerindian culture as a foil against which he claims belonging to Anglo-Christian civilization usually denied black men.

In the same vein, his narrator maintains that he used his influence among the Crow to "disseminate white civilization by exploiting the tribe's belief" for everyone's profits. ${ }^{93}$ Indebted to a capitalist market economy considered a pillar of Euro-American civilization, he admits to "induc[ing] the Crows to devote their undivided attention to trapping, not alone for their own benefit, but [also] for the interest of the [fur-trading] company in whose service I was engaged." 94 Beckwourth further exploits white stereotypes of indigenous "savagery" to justify his simultaneous adoption and rejection of Crow culture. Armed intertribal conflicts intensified from the 1820 s as neighboring indigenous nations fought over territories and the ensuing trade with US merchants.95 Beckwourth does not address this context in his Life and Adventures but rather frames the Crow as strategically inept yet belligerent Natives. They required nonindigenous leadership and "civilizing" influence to be an effective regional power without threatening Anglo-American incursions onto their lands. The narrator suggests that the Crow depended on his tactical and fighting skills and that he strengthened their alliance with whites. "The Crows had never shed the blood of the white man during my stay in their camp, and I did not intend they ever should, If I could raise a voice to prevent it," he states. Moreover, he cites revenge for childhood friends who had been killed by Natives as his motive for joining the Crow. "I fought on [the murdered friends'] behalf against the most relentless enemies of the white man." By framing his role in Crow warfare in his narrative as that of a loyal servant of the United States, Beckwourth asserts his identification

${ }^{91}$ Berkhofer, The White Man's Indian, 28-30, 72-80; Daggar, "The Mission Complex," 468, 475-77; DuVal, The Native Ground, 179, $217-19$.

92 Beckwourth, I 50, also $162,198,233$.

95 Hoxie, 55-56, 61, 65-67, 70-72, 78 . 
with white civilization as "an American citizen" and "sincere lover of my country." 96

However, Beckwourth uses indigenous culture not only to claim an American identity but also to validate Crow society. The narrator of his Life and Adventures confesses his attachment to Crow friends and family, and he praises their communalism. "My heart turns naturally to my adopted people," he admits, and points out that "envy is a quality unknown to the savages." 97 In the same vein, he takes pride in his contributions to the Crow's survival and nostalgically looks back to his adventurous life among them. Beckwourth's book further blurs the boundaries between indigenous and nonindigenous societies in the western borderlands by pointing to the similarities of their ways of life. During the time covered in his narrative, many whites in the region made their living from hunting, trapping, or mobile trading, like their indigenous peers. Beckwourth's text, for instance, depicts white settlers, explorers, and trappers engaging in practices popularly associated exclusively with Amerindians, such as scalp taking or invoking the "Great Spirit." ${ }_{98}^{8}$ The volume even asserts Native people's right to their lands by likening it to the United States' rejection of foreign interventions: The Crow "resent in their hearts the invasion of the immigrant just as any civilized people would, if another nation, without their permission, should cross their territory," the narrator argues. ${ }^{99}$ In pointing to the parallels and entanglements of white and indigenous civilizations, these passages of Beckwourth's book destabilize the idea, affirmed elsewhere in the text, of distinct, unchangeable racial-cultural identities and expose their social construction. Beckwourth thereby subverts racial, spatial, cultural, and narrative norms to attain social agency and economic opportunities commonly denied a black man at the time.

It does not come as a surprise that a memoir steeped in the tradition of the nineteenth-century western American autobiography includes an episode of Indian captivity. However, Beckwourth's depiction of his capture as the beginning of his life among the Crow equally aligns his Life and Adventures with the body of earlier black autobiographies which use experiences of Indian captivity or slavery and the genre of the Indian captivity narrative to convey the black male experience in North America to white audiences and claim opportunities and social agency. Through his life among the Crow, Beckwourth established himself as an (implicitly white) American mountain man and loyal servant of his country. Although personally liberating, this allegiance later led him to help

96 Beckwourth, 198, 232, 529.

97 Ibid., 535, I6I.

98 Ibid., I6, 78, I04; on white western lifeways see DuVal, I 80, 228.

99 Beckwourth, 528 . 
the US Army to extinguish the Plains Indians - and thus also the life of mountain men like himself. Beckwourth's choice of a hybrid autobiographical genre to testify to these complex experiences simultaneously brought the hybridization of the Indian captivity genre in works of black life writing since the mideighteenth century to a closing point.

\section{CONCLUSION}

William Andrews calls Briton Hammon and John Marrant "the first invisible men in black American first-person narrative," as they chose established autobiographical forms to tell their stories. ${ }^{100}$ However, as I have shown here, they, as well as Henry Bibb and James Beckwourth, used episodes of indigenous captivity or enslavement and elements of the popular Indian captivity narrative to render black lives and labors visible to white readers and thus gain agency, mobility, and opportunities within white-dominated society and print culture. The accounts of Briton Hammon, John Marrant, Henry Bibb, and James Beckwourth differ from white-authored memoirs by their subversion of geographic, social, cultural, and narrative boundaries. First, the narratives replace the genre's dominant dichotomy of white/Indian with more complex cultural, religious, national, or class-based distinctions. Second, they at least partially subvert the Anglocentric perspective of the captivity genre to scrutinize white religious hypocrisy, racial stratification, and black chattel slavery, even though they simultaneously affirm white sociocultural hegemony to successfully reach out to their white target audiences. Third, the narratives expose the underlying social construction of racial identities and resist the idea of immutable identity categories. As they either took up or presented themselves as positive foils to indigenous populations, the four authors "successfully insisted on their power of choice in their racial or ethnic self-identifications." twisting elements of the Indian captivity narrative into other forms of life writing such as the comparative captivity account, the African American slave narrative, the spiritual autobiography, or the western borderlands autobiography. This narrative mobility thus enabled them to somewhat overcome race-based social constraints, replace ascribed identities with chosen ones, and claim to belong to British or American society as fellow Christians and/or citizens.

${ }_{100}$ Andrews, To Tell a Free Story, 36.

${ }^{101}$ Laura Browder, Slippery Characters: Ethnic Impersonators and American Identities (Chapel Hill: University of North Carolina Press, 2000), I09. 


\section{AUTHOR BIOGRAPHY}

Astrid Haas is currently a Marie Curie Research Fellow at the Institute of Black Atlantic Research at the University of Central Lancashire. She holds a doctorate in American studies from the University of Münster, Germany, and has taught and researched at different German universities before coming to the UK. She has published the monographs Stages of Agency: The Contributions of American Drama to the AIDS Discourse (201 I) and Lone Star Vistas: Travel Writing on Texas (202I). This article results from her research project, Black Inter-American Mobilities and Autobiography in the Age of Revolutions (1760-1860). The research has received funding from the European Union's Horizon 2020 research and innovation program under the Marie Sklodowska-Curie grant agreement no. 834975 . 